\title{
Uji Teratogenitas Ekstrak Bungo Timah (Peperomia pellucida L. Kunth.,) Terhadap Organ Viseral Embrio Mencit Putih (Mus musculus L.)
}

\author{
YELVITA SARI $^{1}$, WARNETY MUNIR $^{2}$, YOHANES ALLEN $^{3}$ \\ ${ }^{1}$ Program Studi Pendidikan Biologi, STKIP PGRI Sumatera Barat \\ J1. Gunung Pangilun Padang 25000 \\ email: szelvita@yahoo.com \\ ${ }^{2}$ Jurusan Biologi, Fakultas Matematika dan Ilmu Pengetahuan Alam, Universitas Andalas \\ J1. Dr. M. Hatta Kampus Unand Limau Manis Padang 25163 \\ email:warmunir@yahoo.co.id \\ ${ }^{3}$ Jurusan Farmasi, Fakultas Farmasi, Universitas Andalas \\ J1. Dr. M. Hatta Kampus Unand Limau Manis Padang 25163 \\ email: yohannesalen@yahoo.co.id
}

\begin{abstract}
The study on terratogenict effect of Bungo Timah (Peperomia pellucida L. Kunth.,) extract to visceral organ of mice embryo (Mus musculus $\mathrm{L}$ ) was conducted to identify the effect of $P$. pelucida extract to development of mice embryo visceral organ. The Complete Randomize Method, which consist of four, extract dose variation: $0 ; 75 ; 100 ; 125 \mathrm{mg} / \mathrm{kg}$ BW given from the day $6^{\text {th }}-4^{\text {th }}$ of pregnancy were used. The result showed the extract of $P$. pellucida was not teratogenic at $75 \mathrm{mg} / \mathrm{kg}$ BW. While at dose 100 and $125 \mathrm{mg} / \mathrm{kg}$ BW showed visceral organ malformation, the cardiac enlargement, right kidney fission, intestinal diverticula, even thought statistically was not significant $(\mathrm{P}<0,05)$.
\end{abstract}

Keywords: Mus musculus, organ viseral, Peperomia pellucida (L.) Kunth, teratogenitas

\section{PENDAHULUAN}

Penggunaan tumbuh-tumbuhan, ekstrak dan senyawa kimia dari tumbuhan serta turunannya dalam pengobatan berbagai penyakit telah berlangsung sejak lama. Salah satu tanaman yang secara tradisional digunakan sebagai obat adalah Peperomia pellucida (L.) Kunth., yang digunakan sebagai ramuan untuk encok, abses, nyeri rematik, bisul, jerawat, sakit kepala dan gangguan ginjal.

Penelitian mengenai khasiat tumbuhan ini secara ilmiah telah banyak dilakukan. Xu et al., (2006) melaporkan bahwa senyawa kimia yang terdapat dalam $P$. pellucida menunjukkan efek menghambat pertumbuhan sel kanker. $P$. pellucida juga menunjukkan adanya aktivitas antibakteri terhadap Staphylococcus aureus, Bacillus subtilis, Pseudomonas aeroginosa, dan Esherichia coli (Bojo et al., 1994).

Dari hasil uji farmakologi, tumbuhan ini menunjukkan adanya aktivitas anti-inflamasi. Besarnya potensi yang dimiliki oleh tumbuhan P. Pellucida sebagai tumbuhan berkhasiat obat, serta masih minimnya informasi mengenai efek pemakaiannya, termasuk pemakaian pada masa kehamilan memerlukan adanya suatu pengujian untuk mengetahui efek pemakaiannya terhadap janin yang dikandung oleh induk.

Salah satu metode pengujian yang disarankan adalah uji teratologi. Dari berbagai uji teratologi diketahui bahwa organ-organ viseral merupakan organ yang kerap mengalami sasaran teratogen.

Penelitian yang dilakukan oleh Wilson (1979) menunjukkan bahwa paparan singkat suatu teratogen pada tikus hamil akan menghasilkan insiden cacat yang berbeda-beda untuk setiap organ yaitu, cacat otak dengan persentase $35 \%$, cacat mata $33 \%$, cacat jantung $24 \%$, cacat rangka $18 \%$ dan cacat urogenital $6 \%$.

Berdasarkan kenyataan di atas, maka dilakukan penelitian mengenai uji teratogenitas ekstrak bungo timah $(P$. pellucida L. Kunth.,) terhadap organ viseral embrio mencit putih (Mus musculus L.). 


\section{METODE}

Penelitian ini menggunakan Rancangan Acak Lengkap (RAL) dengan 4 perlakuan dan 10 ulangan. Sebagai perlakuan adalah berbagai dosis ekstrak tumbuhan P. pellucid.

Persiapan Hewan Uji. Sebanyak 40 ekor mencit putih betina (Mus musculus L.) dipelihara secara terpisah dengan hewan jantan. Setelah mencit mencapai berat 20-30 gram, mencit betina yang estrus ditempatkan dalam satu kandang (1:5) mulai pukul 17.00 sampai pukul 08.00 WIB esok harinya. Mencit betina diperiksa vulvanya untuk melihat ada tidaknya sumbat vagina yang menandakan hari nol kehamilan. Mencit betina yang hamil dipisahkan dari mencit jantan.

Perlakuan. Pemberian sampel uji dilakukan selama sembilan hari berturut-turut dengan menggunakan jarum oral, mulai dari hari ke-6 sampai hari ke-14 kehamilan dengan dosis $75 \mathrm{mg} / \mathrm{kg} \mathrm{BB}, 100 \mathrm{mg} / \mathrm{kg} \mathrm{BB}, 125 \mathrm{mg} / \mathrm{kg}$ $\mathrm{BB}$ dan $0 \mathrm{mg} / \mathrm{kg} \mathrm{BB}$ sebagai dosis control dngan hanya memberikan CMC 0, $5 \%$. Penetapan range dosis didasarkan pada dosis efektif terhadap hyperuricemia sebesar 100 $\mathrm{mg} / \mathrm{kg} \mathrm{BB}$ (Lovia, 2007).

Pengamatan. Fetus yang telah dikeluarkan dari tubuh induk difiksasi dengan larutan Bouin's selama satu minggu atau lebih. Kemudian dilakukan penyayatan (freehand section) pada bagian sistem organ yang akan diamati (Kameyama, Tanimura, Yasuda, 1980). Organ yang diamati meliputi: jantung, paru-paru, hati, lambung, usus, ginjal, vesika urinaria, ureter, uretra, uterus, dan organ genitalia. Pengamatan dilakukan di bawah mikroskop binokuler trizoom stereo, organ yang mengalami kelainan didokumentasi dengan kamera digital Nikon Coolpix L4.

Analisis Data. Data yang diperoleh diolah secara statistik dengan annova dan apabila terdapat perbedaan nyata dilanjutkan dengan uji DNMRT pada taraf $5 \%$. Hubungan antara dosis uji dengan efek yang timbul dianalisa dengan analisa regresi.

\section{HASIL}

Ekstrak $P$. pellucida yang dberikan secara berulang pada dosis $75 \mathrm{mg} / \mathrm{kg}$ BB tidak menyebabkan munculnya kelainan organ viseral pada embrio mencit, sementara pada dosis 100 dan $125 \mathrm{mg} / \mathrm{kg} \mathrm{BB}$ memperlihatkan adanya kelainan organ viseral, akan tetapi hasil uji statistik tidak menunjukkan perbedaan yang nyata antara kelompok kontrol dan perlakuan.

Tabel 1. Rata-rata kejadian malformasi organ pada fetus mencit (M. musculus) yang induknya diberikan ekstrak $P$. pellucida pada kehamilan hari ke 6-14

\begin{tabular}{cc}
\hline Dosis & Malformasi Organ Viseral \\
\hline P0 & $0 \mathrm{a}$ \\
\hline P1 & $0 \mathrm{a}$ \\
\hline P2 & $0,02 \mathrm{a}$ \\
\hline P3 & $0,04 \mathrm{a}$ \\
\hline
\end{tabular}
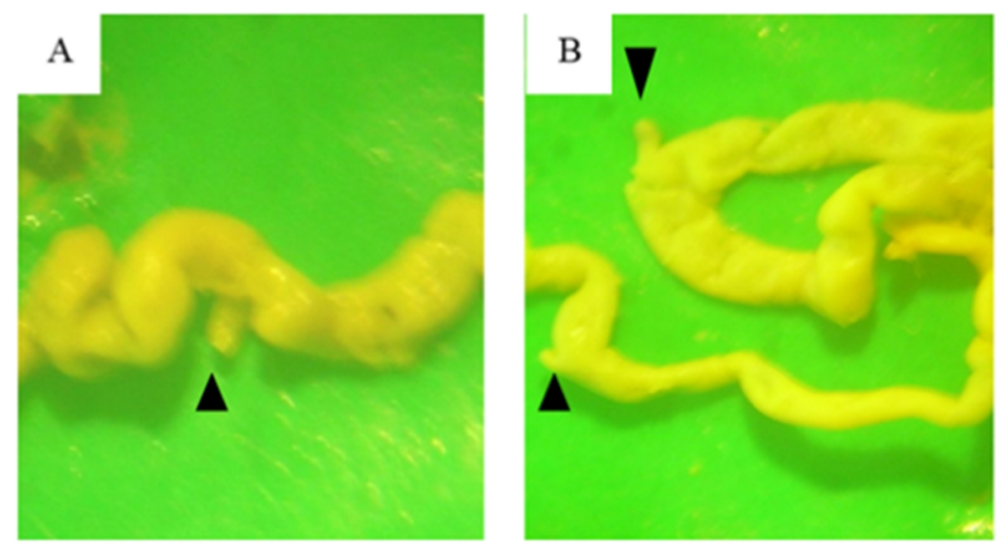

Gambar 1. Tonjolan (T) pada usus fetus mencit umur 18 hari, yang induknya diberikan ekstrak $P$. pellucida dosis $100 \mathrm{mg} / \mathrm{kg} \mathrm{BB}(200 \mathrm{x})$. A. Tonjolan tunggal. B. Tonjolan ganda 
Pada mencit yang diberikan ekstrak $P$. pellucida dengan dosis $100 \mathrm{mg} / \mathrm{kg}$ berat badan ditemukan adanya malformasi organ viseral berupa tonjolan pada usus (Gambar 1). Kelainan ini ditemukan pada dua fetus yang berbeda dari satu induk yang sama. Pada fetus pertama ditemukan satu tonjolan, sedangkan

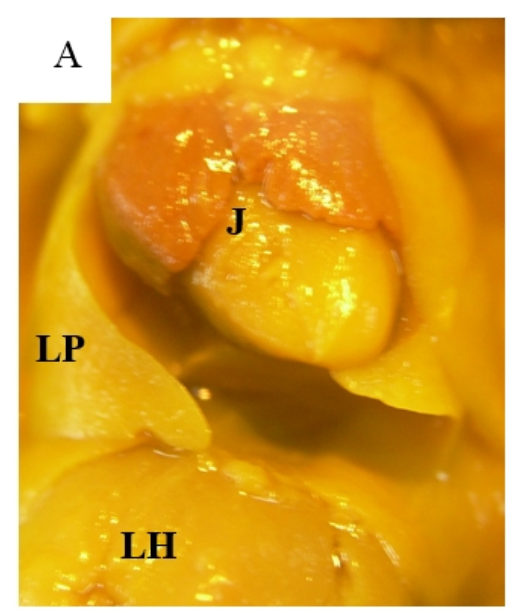

fetus lainnya menunjukkan dua tonjolan pada tempat yang berbeda.

Pada mencit perlakuan dengan dosis 125 $\mathrm{mg} / \mathrm{kg}$ berat badan menunjukkan pembesaran organ jantung. Pada kelainan ini jantung terlihat membesar sehingga menutupi lobus paru-paru.

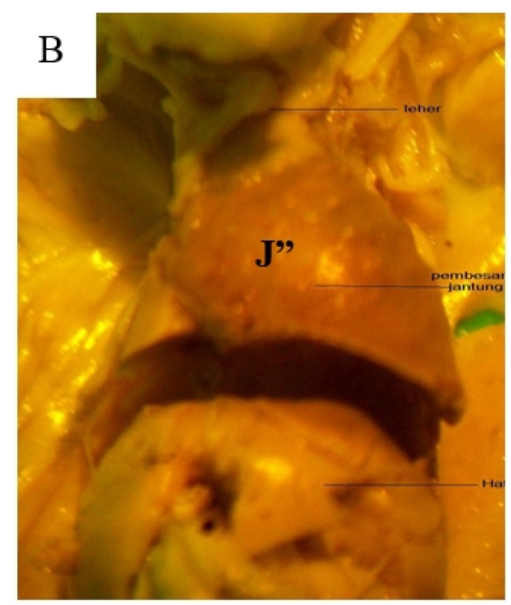

Gambar 2. Jantung mencit umur 18 hari (450x). A. Jantung normal. B. Jantung fetus mencit yang induknya diberi perlakuan ekstrak $P$. pellucida dosis $125 \mathrm{mg} / \mathrm{kg}$ BB yang mengalami pembesaran. (J) jantung; (J") jantung dengan pembesara ukuran ; (LP) lobus paru-paru; (LH) lobus hati.

\section{PEMBAHASAN}

Secara morfologi kelainan ini berupa tonjolan pada usus memiliki kesamaan dengan "diverticulum meckel" yang merupakan kelainan tonjolan yang muncul pada usus halus (Sjamjuhidajat dan Wim de Jong, 2002).Hill (1998) menyatakan bahwa divertikulum merupakan suatu tonjolan tabung buntu yang terbentuk pada masa perkembangan embrio melalui mekanisme interaksi sel-sel epitel dan mesenkim. Interaksi ini terjadi dalam bentuk sinyal-sinyal berkelanjutan yang dilepaskan selama diferensiasi organ yang akan dibentuk. Interaksi antar sel melalui mekanisme penting dalam perkembangan normal embrio. Saxen (1972) cit., Wilson (1979) telah melaporkan bahwa kegagalan kontak antar sel merupakan penyebab munculnya kelainan perkembangan. Kesalahan dalam menanggapi sinyal dari sel induktor dapat saja terjadi sebagai akibat kehadiran suatu substansi asing sehingga terjadi penyimpangan dari bentuk normal.

Dengan adanya kesamaan morfologi kelainan tonjolan usus yang ditemukan dalam penelitian ini dengan "diverticulum meckel", diduga mekanisme terjadinya kelainan ini berlangsung dengan mekanisme yang sama.

Kelainan berupa pembesaran jantung banyak ditemukan pada penyakit jantung bawaan pada manusia. Kelainan ini merupakan tanda penyerta dari cacat jantung bawaan yang sesungguhnya. Kelainan jantung bawaan dapat berupa cacat pada struktur maupun fungsi dari jantung atau pembuluh darah besar pada saat lahir (Kusumaningsih, 2011). Gambaran foto thorax berbagai cacat jantung bawaan menunjukkan adanya pembesaran pada organ jantung (Soetikno, 2009). Sebagian besar penyebab kelainan jantung bawaan pada manusia tidak diketahui dengan pasti. Namun pada kelompok mencit dilaporkan bahwa mutasi gen menjadi penyebab gangguan pembentukan jantung (Shi et al., 2003).

Meskipun ditemukan adanya kelainan organ viseral berupa tonjolan usus pada dosis perlakuan $100 \mathrm{mg} / \mathrm{kg}$ BB dan pembesaran jantung ditemukan pada dosis $125 \mathrm{mg} / \mathrm{kg} \mathrm{BB}$ dalam penelitian ini, namun secara statistik hasil ini tidak menunjukkan signifikansi. Hal ini berarti pemberian ekstrak $P$. pellucida tidak 
memberi pengaruh terhadap perkembangan organ viseral embrio mencit putih Mus musculus selama masa kehamilan. Hal tersebut sejalan dengan penelitian yang dilakukan oleh Ramadhalia (2007) dimana pemberian ekstrak P. pellucida terhadap mencit putih (Mus musculus) tidak bersifat mengganggu perkembangan rangka pada fetus yang terbentuk.

\section{KESIMPULAN}

Dari penelitian yang telah dilakukan dapat disimpulkan bahwa: pemberian ekstrak $P$. pellucida (L.) Kunth., pada dosis $75 \mathrm{mg} / \mathrm{kg}$ BB tidak menimbulkan efek teratogenitas terhadap organ viseral embrio mencit. Pada dosis 100 dan $125 \mathrm{mg} / \mathrm{kg} \mathrm{BB}$ memperlihatkan adanya kelainan organ viseral tetapi secara statistik tidak menunjukkan efek yang signifikan.

\section{DAFTAR PUSTAKA}

Bojo AC, Albano-Garcia E, Poscidio GN. 1994. The Antibacterial Activity of Peperomia pellucida (L.) HBK (Piperaceae). http://searchmed scape.com. Diakses 30 Oktober 2006.

Hill M. 1998. UNSB Embriology. http://embryology.med.unsw.edu.au. Diakses 15 Januari 2008.

Khan MR and Omoloso AD. 2002. Antibacterial activity of Hygrophilla stricta and Peperomia pellucida. [Abstract]. Fitoterapia. vol 73 (3): 251-4.

Kameyama K, Tanimura T, Yasuda M (editor). 1980. Editorial section of Congenital
Anomalies. Journal of Congenital Anomalies. vol (20): 25-106.

Kusumaningsih FK. 2011. Tes Skrining Penyakit Jantung Kongenital Pada Bayi Baru Lahir Menggunakan Pulse Oxymetry [Tesis]. Jakarta: Universitas Indonesia.

Lovia S. 2007. Uji Efek Anti Hyperucemia Dari Fraksi Tanaman Peperomia pellucida (L.) Kunth Terhadap Kadar Asam Urat Serum dan Urin Mencit Putih Jantan [Skripsi)]. Padang: Jurusan Farmasi FMIPA Universitas Andalas.

Ramadhalia. 2007. Pengaruh Pemberian Ekstrak Peperomia pellucida (L.) Kunth Terhadap Embrio Mencit Putih (Mus musculus) L. [Skripsi]. Padang: Jurusan Biologi FMIPA. Universitas Andalas.

Shi W, Chen H, Sun J, Buckley S, Zhao J, Anderson KD. 2003. TACE is Required for Fetal Murine Cardiac Development and Modeling. Developmental Biology. vol 261: $371-380$.

Sjamjuhidajat $\mathrm{R}$ dan de Jong $\mathrm{W}$ (Editor). 2002. Buku Ajar Ilmu Bedah. Jakarta: EGC.

Soetikno RD. 2009. Gambaran Foto Toraks Pada Congenital Heart Disease. Bandung: Universitas Padjajaran.

Wilson JG. 1979. Environment and Birth Defect. New York and London: Academic Press.

Xu S, Li N, Ning MM, Zhou $\mathrm{CH}$, Yang QR, Wang MW. 2006. Bioactive Compounds of Peperomia pellucida Kunth. http://pubs.acs.org. Diakses 10 November 2006. 